\title{
ANALISIS PENGARUH KINERJA KEUANGAN DAN UKURAN PERUSAHAAN TERHADAP HARGA SAHAM PERUSAHAAN DALAM INDEKS LQ45 DI BURSA EFEK INDONESIA $2012-2016$
}

\author{
Nola Hasrina Lova, Aminar Sutra Dewi \\ Sekolah Tinggi Ilmu Ekonomi KBP \\ nolahasrinalova12@gmail.com
}

\begin{abstract}
The share price of companies listed on the LQ45 index has declined almost all sectors to decline in stock prices, Unless mining and infrastructure sectors are still moving in the green zone. Performance in this research is represented by Return On Equity and company size measured by Total Asset. In this study aims to determine whether the influence of Return On Equity on stock prices and the size of the Company to the stock price of the company. The method used to determine the sample is by purposive sampling method, the data used is sekunder date in the form of financial report data from companies listed on the LQ45 index. To test the variables using panel data regres sion are Common Effects Models (CEM), Fixed Effects Models (FEM), and Random Effects Models (REM). The results of this study indicate that financial performance does not affect the stock price of the company, while the size of the company does not affect the stock price.
\end{abstract}

Keywords: Stock Price, Return On Asset, Company Size

\section{PENDAHULUAN}

Harga saham dapat diartikan sebagai jumlah atau harga dari surat berharga yang dimiliki seseorang yang akan dibeli sesuai dengan penelitian kinerja terhadap perusahaan. Dalam dunia usaha harga saham perusahaan adalah suatu patokan dimana apakah perusahaan akan mengalami perkembangan atau tidaknya. Apabila harga saham tinggi itu menggambarkan perusahaan tersebut mempunyai peluang perkembangan perusahaan dan apabila harga saham turun maka perusahaan tersebut akan mengalami kurangnya investasi dari investor yang mengakibatkan terganggunya perkembangan perusahaan.

Menurut (Suselo, 2015) faktor yang mempengaruhi harga saham baik yang berasal dari fundamental perusahaan maupun makro ekonomi perusahaan. Secara umum, faktor funda- mental perusahaan yang banyak dikaji sebelumnya meliputi: Return on total assets (ROA) Merupakan rasio untuk mengukur kemampuan manajemen dalam mengelola aset nya, Return on equity (ROE) Merupakan rasio yang mengukur kemampuan dalam mengelola kapital yang ada untuk mendapatkan net income Price to book value (PBV) Merupakan perbandingan antara harga saham dan nilai buku saham Earning price share (EPS) Adalah pemberian keuntungan yang diberikan pada para pemegang saham dari setiap 
lembar saham yang dimiliki. Price earning ratio (PER) Merupakan perbandingan antara harga pasar atau saham dengan earning per share dari saham yang bersangkutan. Debt equity ratio (DER) Merupakan rasio yang mengukur sejauh mana perusahaan untuk memenuhi kewajiban jangka panjang.

Harga saham pada penelitian ini dipengaruhi oleh kinerja keuangan perusahaan dan ukuran perusahaan. Kinerja keuangan perusahaan dan ukuran peruahaan adalah beberapa penilaian terhadap pembelian saham pada perusahaan. Kinerja Keuangan adalah salah satu penunjang dimana investor dalam menilai perusahaan untuk melakukan investasi. Selaian kinerja keuangan yang mempengaruhi harga saham perusahaan variabel lain yang mempengaruhi adalah ukuran perusahaan. Ukuran perusahaan digunakan untuk mengukur kecil atau besar nya suatu perusahaan yang dapat dilihat dari total aktiva perusahaan dan dilihat dari apakah perusahaan mampu menggunakan total aktiva se efisien mungkin.

Indikator yang mengukur kinerja keungan Pengukuran kinerja keuangan perusahaan adalah dengan menilai laporan keuangan perusahaan. Menurut (Harahap,2006) dalam (Hapsari, 2013) Laporan keuangan sebagai laporan yang menggambarkan kondisi keuangan dan hasil usaha suatu perusahaan pada saat tertentu atau jangka waktu tertentu. Laporan ini terdiri dari neraca, laporan laba rugi, laporan arus kas dan laporan perubahan posisi keuangan. Dalam penelitian (Hapsari, 2013) Analisa Laporan Keuangan. Rasio keuangan merupakan satu dari beberapa cara yang dapat digunakan dalam menganalisis keadaan keuangan perusahaan, hal ini yang sangat umum dilakukan di mana hasilnya akan memberikan pengukuran relative dari operasi perusahaan.

Secara umum, rasio keuangan dibagi menjadi 4 jenis, antara lain : (1) Rasio Likuiditas adalah rasio yang bertujuan untuk mengetahui kemampuan perusahaan dalam membayar kewajiban jangka pendek. (2) Rasio Solvabilitas mengukur sejauh mana perusahaan mendanai usahanya dengan membandingkan antara dana sendiri yang telah disetorkan dengan jumlah pinjaman dari para kreditur. (3) Rasio Profitabilitas menggambarkan kemampuan perusahaan mendapatkan laba melalui semua kemampuan dan sumber yang ada seperti kegiatan penjualan, kas, modal, jumlah karyawan, jumlah cabang dan sebagainya. (4) Rasio Aktivitas menggambarkan aktivitas yang dilakukan perusahaan dalam menjalankan operasinya, baik dalam kegiatan penjualan, pembelian dan kegiatan lainnya.

Menurut (Sitompul, 2008) mengatakan Ukuran perusahaan dapat dinyatakan dalam total aktiva, penjualan dan kapitalisasi pasar. Semakin besar total aktiva, penjualan dan kapitalisasi pasar maka semakin besar pula ukuran perusahaan itu. Perusahaan yang memiliki laporan keuangan yang bagus dan ukuran perusahaan yang memiliki karakteristik akan meningkatkan harga saham perusahaan. Semakin tingga haraga saham perusahaan akan semakin meningkatkan kualitas dan profitabilitas perusahaan. Jika semakin baik kinerja keuangan suatu perusahaan maka minat investor atas permintaan saham semakin naik, yang kemudian berimbas pada kenaikan harga saham itu sendiri, jika harga saham naik maka nilai perusahaan pun ikut naik (Ulfa, 2014) 
(Nugrahani, 2016) mendefinisikan ukuran perusahaan adalah seperangkat kebijaksanaan yang ditetapkan dengan baik yang harus dilaksanakan oleh perusahaan yang bersaing secara global. Dalam penelitian ini pengukuran ukuran perusahaan dinyatakan dalam lambang SIZE. Ukuran perusahaan diproksikan ke dalam log total aset, karena nilai aset relatif lebih stabil dibanding nilai pasar dan penjualan.

Berdasarkan uraian tentang ukuran perusahaan di atas, maka dapat disimpulkan bahwa ukuran perusahaan merupakan suatu indikator yang dapat menunjukkan suatu kondisi atau karakteristik suatu organisasi atau perusahaan dimana terdapat beberapa parameter yang dapat digunakan untuk menentukan ukuran (besar/kecilnya) suatu perusahaan, seperti banyaknya jumlah karyawan yang digunakan dalam perusahaan untuk melakukan aktivitas operasional perusahaan, jumlah aktiva yang dimiliki perusahaan, total penjualan yang dicapai oleh perusahaan dalam suatu periode, serta jumlah saham yang beredar.

Kinerja keuangan adalah suatu laporang keuangan perusahaan yang menunjukan keadaan perusahaan dimana akan digunakan untuk bahan pertimbangan bagi perusahaan untuk melakukan tindakan selanjutnya maupun bagi masyarakat untuk menilai kelancaran perusahaan tersebut sebelum melakukan tindakan. Kinerka keungan akan mempengaruhi harga saham perusahaan dengan fluktuasi nya yang akan di lihat oleh investor dalam melakukan pembelian saham. Harga saham dapat diartikan jumlah atau harga dari surat berharga yang dimiliki perusahaan yang akan di beli oleh investor berdasarkan penilaian investor terhadap perusahaan.

Hasil penelitian (Rinati, 2008) menunjukkan bahwa secara serempak (bersama-sama) variabel Net Profit Margin (NPM), Return On Assets (ROA) dan Return On Equity (ROE) memiliki pengaruh yang signifikan dan positif terhadap harga saham, sedangkan secara parsial (masing-masing) hanya Return On Assets (ROA) yang memiliki pengaruh signifikan terhadap harga saham. Penelitian (Rani, Nyoman, \& Diantini, 2015) menemukan hasil yang sama dimana return on equity mempengaruhi harga saham secara signifikan dan positif. Nilai return on equity yang tinggi dapat meningkatkan harga saham perusahaannya, sehingga hipotes pada proposal penelitian ini menjadi: $\mathbf{H}_{\mathbf{1}}$ : Diduga kinerja keuangan perusahaan dengan menggunakan ROE berpengaruh positif dan signifikan terhadap harga saham.

(Setiyono, 2016) Ukuran perusahaan (size) menggambarkan besar kecilnya suatu perusahaan yang ditunjukkan oleh total aktiva, jumlah penjualan, rata-rata tingkat penjualan dan rata-rata total aktiva. Dalam penelitian ini ukuran perusahaan diukur dengan menggunakan total aktiva. Tingkat pengembalian (return) saham perusahaan besar lebih besar dibandingkan return saham pada perusahaan berskala kecil, karena tingkat pertumbuhan perusahaan besar relatif lebih besar dibanding perusahaan kecil. Dalam penelitian ini menyimpulkan bahwa Debt to Equity Ratio (DER) dan Earning Per Share (EPS) secara signifikan berpengaruh positif terhadap Return Saham, sedangkan Current Ratio (CR), Return On Asset (ROA), dan Ukuran Perusahaan tidak berpengaruh secara signifikan positif terhadap Return Saham. 
Pada penelitain (Sitompul, 2008) yang berjudul Analisis Pengaruh Kinerja Keuangan dan Ukuran Perusahaan Terhadap Harga saham Infrastructure, Utilities \& Transportation Yang Terdaftar Di Bursa Efek Indonesia mengatakan bahwa ukuran perusahaan ini berpengaruh signifikan dan positif terhadap harga saham perusahaan. Tetapi pada penelitian (Raningsih \& Dwianan Putra, 2015) yang berjudul Pengaruh Rasio-Rasio Keuangan Dan Ukuran Perusahaan Pada Return Saham. Hasil penelitian menunjukkan bahwa rasio profitabilitas dan leverage berpengaruh positif terhadap return saham, rasio likuiditas berpengaruh negatif terhadap return saham, sedangkan rasio aktivitas, dan ukuran perusahaan tidak berpengaruh terhadap return saham. Berdasarkan penjelasan diatas maka hipotesis ke dua dalam penelitian ini dirumuskan $: \mathbf{H}_{2}$ : Diduga ukuran perusahaan tidak berpengaruh positif dan signifikan terhadap harga saham

\section{METODE PENELITIAN}

Jenis penelitian yang diambil dalam penelitian ini berupa jenis kuantitatif. Jenis kuantitatif merupakan suatu metode yang bersifat angka-angka dan kemudian dapat diuji secara hipotesisi. Penelitian kautitatif adalah penelitian yang menunjukkan arah hubungan antara variabel bebas dengan variabel terikat (Sugiyono, 2015).

Objek penelitian adalah segala sesuatu yang menjadi pusat perhatian seseorang dalam melakukan sebuah penelitian (Sugiyono, 2015) maka objek yang diambil dalam penelitian ini adalah perusahaan dalam indeks LQ45 pada Bursa Efek Indonesia Periode 2012-2016.

Populasi adalah wilayah generalisasi yang terdiri atas subjek/objek yang mempunyai kuntitas tertentu yang ditetapkan oleh peneliti untuk dipelajari dan kemudian ditarik kesimpulannya (Sugiyono, 2015). Dengan kata lain populasi merupakan suatu kumpulan dari keseluruhan baik itu orang, barang, perusahaan yang mana dapat menjadi objek penelitian. Populasi dalam penelitian ini adalah seluruh perusahaan pada indeks LQ45 di Bursa Efek Indonesia (BEI) tahun 20122016 yang berjumlah 45 populasi.

Sampel adalah bagian dari jumlah dan karakteristik yang dimiliki oleh populasi (Sugiyono, 2015). Sampel yang digunakan pada penelitian ini dengan metode purposive sampling yang bejumlah 17 yang diambil berdasarkan kriteria yang ditentukan yaitu:

1. Perusahaan yang terdaftar pada indekx LQ45 di Bursa Efek Indonesia dari tahun 2012-2016

2. Perusahaan yang memiliki profit yang bagus

3. Perusahaan yang mempunyai data harga saham tahun 2012-2016 meningkat dan bagus

4. Perusahaan yang mempunyai laporan keuangan dari tahun 2012-2016

Jenis penelitian yang diambil dalam penelitian ini berupa jenis kuantitatif. Jenis kuantitatif merupakan suatu metode yang bersifat angka-angka dan kemudian dapat diuji secara hipotesisi atau data kuantitatif adalah data yang berbentuk angka atau data yang di angkakan (Sugiyono, 2015). Sumber data yang digunakan dalam penelitian ini adalah sumber data sekunder. Data sekunder adalah suatu data yang sudah ada atau data yang sudah di pumlikasikan (Sugiyono, 2015) 
Teknik pengumpulan data dalam penelitian ini adalah dengan teknik dokumentasi. Teknik dokumentasi yaitu teknik pengumpulan data-data yang telah menjadi suatu dokumentasi yang telah dipublikasikan seperti laporan keuangan oleh perusahaan pada index LQ45 di Bursa Efek Indonesia melalui situs resmi www.idx.co.id www.yahoofinance.com

Variabel yang dugunakan dalam penelitian ini adalah variabel bebas (idependent variable) dan variabel terikat (dependent variable)

\section{Tabel 1}

Defenisi Operasional Variabel

\begin{tabular}{|c|c|c|c|}
\hline Variabel & Defenisi & Pengujian & Sumber \\
\hline $\begin{array}{l}\text { 1. Harga } \\
\text { Saham }\end{array}$ & $\begin{array}{l}\text { Return saham merupakan } \\
\text { hasil yang diperoleh dari } \\
\text { investasi yang dilakukan } \\
\text { investor. Return yang } \\
\text { maksimal adalah hal yang } \\
\text { diinginkan setiap investor } \\
\text { dalam investasinya. } \\
\text { (Setiyono, 2016) }\end{array}$ & $\mathrm{Rit}=\frac{(\mathrm{Pt}-\mathrm{Pt}-1)}{\mathrm{Pt}-1}$ & $\begin{array}{l}\text { Setiyono } \\
2016\end{array}$ \\
\hline 2. $\mathrm{ROE}$ & $\begin{array}{l}\text { ROE adalah perbandingan } \\
\text { antara laba bersih bank } \\
\text { dengan ROE modal } \\
\text { sendiri.(Susilowati \& } \\
\text { Utiyati, 2016) }\end{array}$ & $\begin{aligned} \text { ROE }= & \frac{\text { Laba bersih }}{\text { x100\% Modal }} \\
& \text { sendiri }\end{aligned}$ & $\begin{array}{l}\text { Susilow } \\
\text { ati \& } \\
\text { Utiyati } \\
2016\end{array}$ \\
\hline 3. & $\begin{array}{l}\text { Total Aktiva adalah } \\
\text { perbandingan besar atau } \\
\text { kecilnya perusahaan dalam } \\
\text { pengukuran perusahaan. }\end{array}$ & $\begin{array}{l}\mathrm{TA}=\mathrm{LN} \text { (Total } \\
\text { Aktiva) }\end{array}$ & $\begin{array}{l}\text { (Sitomp } \\
\text { ul, } \\
2008)\end{array}$ \\
\hline
\end{tabular}

\section{Statistik Deskriptif}

Statistik deskriptif adalah statistik yang berfungsi untuk mendeskripsikan atau memberikan gambaran terhadap ojek yang diteliti melalui data sampel atau populasi sebagaiman adanya, tanpa melakukan analisis dan membuat kesimpulan yang berlaku untuk umum. Pada statistik deskriptif ini, akan dilakukan cara-cara penyajian data, dengan tabel biasa ataupun distribusi frekuensi ; grafik garis maupun batang ; diagram lingkaran ; pictigram ; penjelasan kelompok melalui modus, median,mean dan variasi kelompok melalui rantang dan simpangan baku (Sugiyono, 2015)

\section{Uji Asumsi Klasik}

\section{Uji Normalitas}

Uji normalitas bertujuan menguji apakah dalam model regresi, variabel pengganggu atau residual memiliki residual normal atau tidak. Uji normalitas data bertujuan untuk mengetahui apakah distribusi penyampelan variabel yang digunakan dalam penelitian telah terdistribusi normal atau tidak normal (Fahruri, 2017). Uji normalitas pada penelitian ini menggunakan Jarque-Bera. Dimana apabila Jarque-Bera > tingkat alpha 5\% maka data terdistribusi secara normal dan 
sebaliknya apabila Jarque-Bera < tingkat alpha 5\% maka tidak terdistribusi normal (Winarno, 2015).

\section{Uji Multikolinearitas}

Uji mulikolonieritas dilakukan guna mengetahui indikasi asumsi klasik tersebut. Uji ini bertujuan menguji apakah model regresi ditemukan adanya pengaruh antar variabel bebas atau independent (Fahruri, 2017). Uji multikolonieritas kondisi adanya hubungan linerar antarvariabel independen (Winarno, 2015). Uji multikolenearitas dilakukan dengan dengan model regresi linier klasik apabila memiliki independen lebih dari satu. Syarat tidak terjadi Multikolonieritas adalah jika nilai korelasi antar variabel independen $<0$,8. Jika nilai korelasi > 0,8 maka terjadi multikolonearitas.

\section{Uji heteroskedastisitas}

Uji heteroskedastisitas bertujuan menguji apakah dalam model regresi terjadi ketidaksamaan variance dari residual satu pengamatan ke pengamatan yang lain (Sitompul, 2008). Uji heteroskedastisitas dilakukan dengan uji white untuk mengetahui apakah data tersebar atau tidak. Cara melihat uji heteroskedastisitas dengan melihat white heteroskedasttisity test dimana probability Obs*R-squered $<5 \%$ ( alpha) maka dapat dikatakan bahwa data tersebut bersifat heteroskedastisitas dan sebaliknya (Winarno, 2015).

\section{Uji Pemilihan Model}

\section{Metode Common Effect (CEM)}

Ruri (2007) menyatakan bahwa Model Common Effect menggabungkan data cross section dengan time series dan menggunakan metode OLS untuk mengastimasi model data panel tersebut. Model ini merupakan model paling sederhana dibandingkan dengan kedua model lainya. Model ini tidak dapat membedakan varians antara silang, dan bukan bervariasi secara random

\section{Metode Fixed Effecd (FEM)}

Model Fixed Effect adalah model dengan intercept berbeda-beda untuk setiap subjek (cross section), tetapi slope setiap sujek tidak berubah seiring waktu. Model ini mengasumsikan bahwa intercept adalah berbeda setiap subjrk lainya digunakan variabel dummy. Model ini sering disebut dengan model Least Square Dummy Variables (LSDV) (Ruri 2007).

\section{Metode Random Effect (REM)}

Random Effect disebabkan variasi dalam nilai dan arah hubungan antara subjek diasumsikan random yang dispesifikasikan dalam bentuk residual. Model ini mengistimasikan data panel yang variabel residual diduga memiliki hubungan antar subjek. Ruri, 2007 mengemukakan bahwa model random effect digunakan untuk mengatasi.

kelemahan model fixed effect yang menggunakan variabel dummy. Metode analisis data panel dengan metode random effect harus memenuhi persyaratan yaitu jumlah cross section harus lebih besar dari pada jumlah variabel penelitian. Untuk menentukan model mana yang terbaik antar Common Effect Model, Fixed Efect Model dan Random Effect Model maka dialkukan pengujian lebih lanjut dengan menggunakan Chow-Test atau Likehood Ratio Test dan Hausman Test. Asumsi yang digunakan dalam pengujian Chow-Test yaitu:

H0: Model mengikuti pool 
Ha: Model mengikuti Fixed

Dasar pengambilan keputusan yang digunakan adalah jika probabilitas (signifikan) >0.05, maka H0 diterima, dan sebaliknya jika Probabilitas (signifikan) $<0.05$ maka Ha ditolak.

Sedangkan asumsi yang digunakan dalam pengujian Hausman Test yaitu:

H0: Model mengikuti random

Ha: Model mengikuti Fixed

Dasar pengambilan keputusan yang dipilih adalah jika Probabilitas (signifikan) > 0.05, maka H0 diterima dan Ha ditolak, sebaliknya jika probabilitas (signifikan) $<0.05$ maka H0 di tolak dan Ha diterima.

\section{Analisis Regresi Data Panel}

Persamaan regresi yang digunakan dalam analisis data panel adalah sebagai berikut:

\section{Uji Hipotes is}

$$
\begin{array}{ll}
\text { YIt } & =\alpha+\beta 1 \text { ROE it }+\beta 2 \text { TA it }+\mathrm{e} \\
\text { YIt } & =\text { Harga Saham pada waktu } \mathrm{t} \\
\text { ROE It } & =\text { Return On Equity pada waktu } \mathrm{t} \\
\text { TA it } & =\text { Total Asset pada waktu } \mathrm{t} \\
\alpha & =\text { Intercept } \\
\text { B1 dan } \beta 2 & =\text { Koefisien Regresi }
\end{array}
$$

Hartanto (2004) menyatakan bahwa uji statistik t pada dasarnya menunjukkan seberapa jauh pengaruh suatu variabel bebas secara individual dalam menerangkan variasi variabel terkait. Hipotesis nol (H0) yang hendak diuji adalah diduga bahwa variabel bebas secara signifikan tidak berpengaruh terhadap variabel terikat.

Hipotesis yang akan dibuktikan adalah:

H1o: Tidak ada pengaruh signifikan antara kinerja keungan (ROE) terhadap Harga Saha

H1a: Terdapat pengaruh signifikan antara kinerja keungan (ROE) terhadap Harga Saham

H2o: Tidak ada pengaruh signifikan antara Ukuran Perusahaan terhadap Harga Saham

H2a: Tidak ada pengaruh signifikan antara Ukuran Perusahaan terhadap Harga Saham

Uji signifikansi menggunakan t-test dilakukan dalam penelitian dengan level of significant $5 \%(0.05)$

a. Jika nilai signifikansi > 0.05 maka Ho ditolak dan Ha diterima, Ho diterima sehingga ROE dan TA tidak berpengaruh terhadap Harga saham.

b. Jika nilai signifikansi $<0.05$ maka Ha diterima, Ho ditolak, sehingga ROE dan TA berpengaruh terhadap Harga Saham. 


\section{HASIL DAN PEMBAHASAN}

\section{Statistik Deskriptif Variabel penelitian}

Tabel 2

Hasil Uji Statistik

\begin{tabular}{lccc}
\hline & Harga saham & ROE & TA \\
\hline Mean & 13939.81 & 18.59376 & 4.796 .217 .349 \\
Maximum & 66106.82 & 90.84 & 53.500 .322 .659 \\
Minimum & 3263.5 & 1.01 & 182.274 \\
standar deviasi & 13087.33 & 11.6811 & 11606208357 \\
Obsevasi & 85 & 85 & 85 \\
\hline \multicolumn{4}{c}{ Dari tabel di atas dapat di lihat bahwa pada observasi yang berjumlah 85 }
\end{tabular}

data. Data harga saham menunjukkan bahwa nilai tertinggi (maximum) berada pada nilai 66106,82 yang diperoleh oleh perusahaan PT. Gudang Garam Tbk pada tahun 2016, nilai minimal (minimum) sebesar 3263,5 yang dimiliki oleh perusahaan PT. Indocement Tunggal Prakarsa Tbk 2012, sedang kan nilai ratarata (mean) sebesar 13939.81 dan nilai standard deviasi nya sebesar 13087.33yang menunjukkan bahwa simpangan harga saham dikatakan cukup baik.

Pada variabel bebas ROE mempunyai nilai tertinggi (maximum) dengan nilai 90.84 yang berada pada perusahaan Tower Bersama Infrastruktur Tbk tahun 2015, nilai terendah (minimum) berada pada perusahaan Mitra Adiperkasa Tbk dengan nilai 1,01 pada tahun 2015, sedangkan nilai rata-rata(mean) dari keseluruhan dengan nilai 18.59376 dengan standar deviasinya sebesar 11.6811 yang menunjukkan bahwa variabel profitabilitas (ROE) dikatakan baik.

Variabel total asset mempunyai nilai tertinggi (maximum) dengan nilai 53.500.322.659 yang berada pada perusahaan PT. Jasa Marga (Persero) Tbk pada tahun 2015, nilai terendah (minimum) berada pada perusahaan dengan nilai 182.274 berada pada perusahaan PT.Astra Internasional Tbk pada tahun 2015 , sedangkan nilai rata-rata (mean) dengan nilai 4.796.217.349 dan standar deviasi sebesar 11.606.208.357, yang menggambarkan bahwa total asset dalam keadaan baik.

\section{Uji Asumsi Klasik \\ Uji Normalitas}

Uji normalitas pada penelitian ini menggunakan Jarque-Bera. Dimana apabila tingkat signifikan > tingkat alpha 5\% maka data terdistribusi secara normal dan sebaliknya apabila tingkat signifikan < tingkat alpha 5\% maka tidak terdistribusi normal. 
Tabel 3

Hasil Uji Normalitas

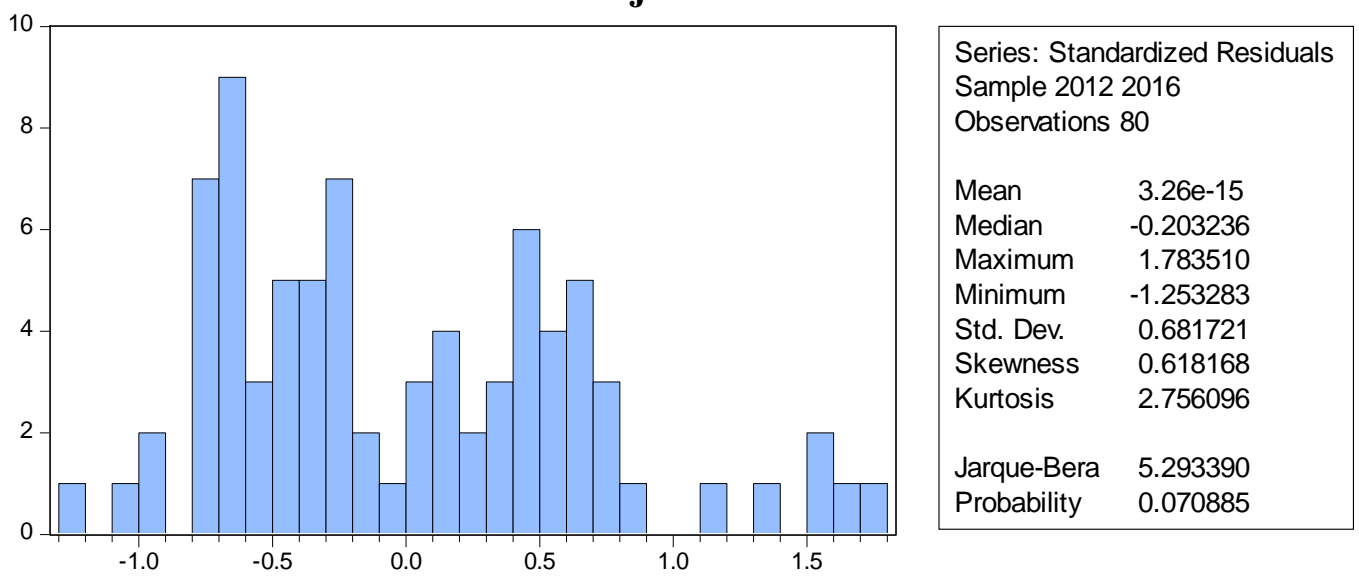

Sumber: Olahan SPSS 16

Dari tabel 3 menunjukkan nilai Jarque-Bera sebesar 5.293390 dengan nilai probability besar dari a $(0.070885>0.05)$ hasil ini menunjukan bahwa data terdistribusi normal. Data tersebut telah terdistribusi normal setelah dilakukan transformasi data menggunakan logaritma natural (Log).

\section{Uji Multikolinearitas}

Uji multikolenearitas dilakukan dengan dengan model regresi linier klasik apabila memiliki independen lebih dari satu. Syarat tidak terjadi Multikolonieritas adalah jika nilai korelasi antar variabel independen $<0,8$. Jika nilai korelasi > 0,8 maka terjadi multikolonearitas.

\section{Tabel 4}

Hasil Uji Multikolinearitas

\begin{tabular}{lll}
\hline & Log ROE & Log TA \\
\hline Log ROE & 1.00000 & $-0,292689$ \\
Log TA & $-0,292689$ & 1.000000 \\
\hline
\end{tabular}

\section{Sumber : Olahan SPSS}

Dari tabel 4 dapat dilihat bahwa Uji multikolenearitas dilakukan dengan dengan model regresi linier klasik apabila memiliki independen lebih dari satu. Syarat tidak terjadi Multikolonieritas adalah nilai korelasi antar variabel independen $<0,80$. Jika nilai korelasi $>0,80$ maka terjadi multikolonearitas. Dari data yang telah di uji terbebas dari masalah Multikolinearitas karena berada dibawah $0,80(-0,292689<0.80)$.

\section{Heteroskedastisitas}

Cara melihat uji heteroskedastisitas dengan melihat white heteroskedasttisity test dimana probability Obs*R-squered $<5 \%$ ( alpha) maka dapat dikatakan bahwa data tersebut bersifat heteroskedastisitas dan sebaliknya (Winarno, 2015). 


\section{Tabel 5 \\ Uji Heteroskedastisitas}

Dependent Variable: ABRESID

Method: Panel Least Squares

Date:03/04/18 Time:20:55

Sample:20122016

Periods included: 5

Cross-sections included: 16

Total panel (balanced) observations: 80

\begin{tabular}{lrrrr}
\hline \multicolumn{1}{c}{ Variable } & Coefficient & Std. Error & t-Statistic & Prob. \\
\hline \hline C & 0.589002 & 0.082129 & 7.171705 & 0.0000 \\
ROE & 0.000307 & 0.003536 & 0.086740 & 0.9311 \\
\multicolumn{1}{c}{ TA } & $-4.56 \mathrm{E}-12$ & $3.44 \mathrm{E}-12$ & -1.326502 & 0.1886 \\
\hline \hline & & & \\
R-squared & 0.022999 & Mean dependent var & 0.574085 \\
Adjusted R-squared & -0.002378 & S.D. dependent var & 0.361937 \\
S.E. of regression & 0.362367 & Akaike info criterion & 0.844460 \\
Sum squared resid & 10.11085 & Schwarz criterion & 0.933786 \\
Log likelihood & -30.77838 & Hannan-Quinn criter. & 0.880273 \\
F-statistic & 0.906295 & Durbin-Watson stat & 0.590838 \\
Prob(F-statistic) & 0.408284 & & \\
\hline \hline
\end{tabular}

Sumber : Output SPSS

Uji Heteroskedastisitas dilakukan dengan Uji White. Cara melihat uji heteroskedastisitas dengan melihat white heteroskedasttisity test dimana probability $R$-squered $<5 \%$ ( alpha) maka dapat dikatakan bahwa data tersebut bersifat heteroskedastisitas dan sebaliknya apabila probabiliti $>5 \%$ maka dapat dikatakan bebas dari Heteroskedastisitas. Dari data yang telah di uji bahwa data terbebas dari masalah Heteroskedastisitas karena nilai probabilitas > 5\% yaitu sebesar ROE $0.9311>0,05$ dan TA $0.1886>0,05$. 


\section{Pemilihan Regresi Data Pane Uji Regresi Data Panel}

Tabel 6

Common Effect Model

Dependent Variable: ABRESID

Method: Panel Least Squares

Date:03/04/18 Time:20:55

Sample:2012 2016

Periods included: 5

Cross-sections included: 16

Total panel (balanced) observations:

80

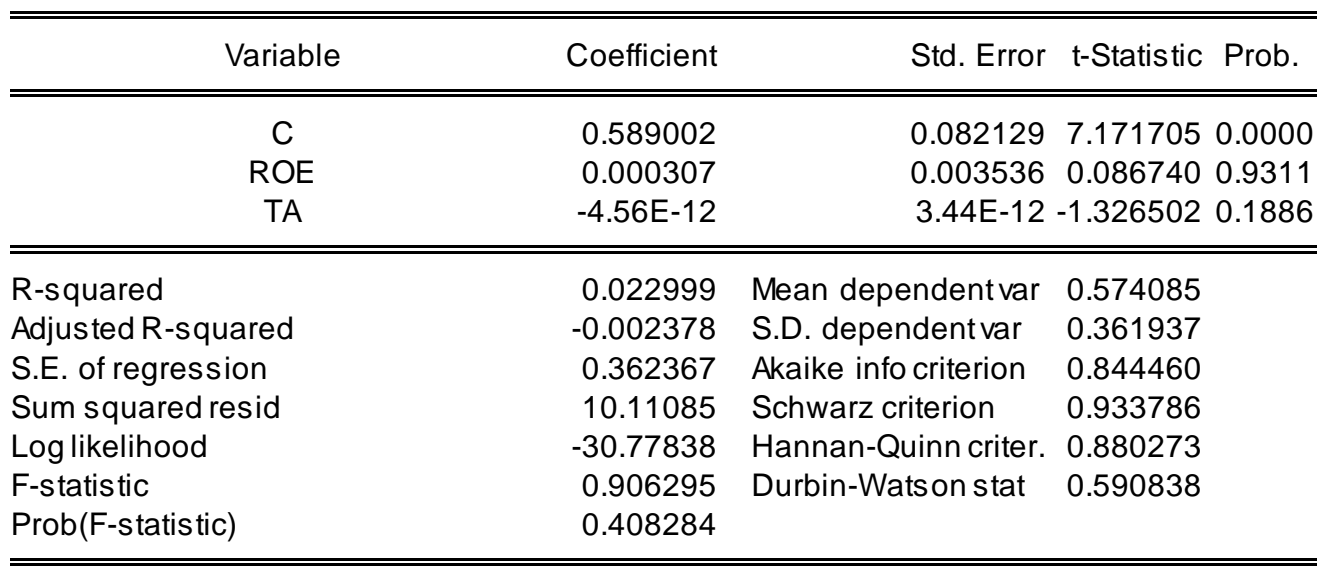

Sumber: EViews

Model ini menggabungkan antara Cross section dan Time series dengan menggunakan metode OLS untuk mengastimasi model data panel tersebut.Nilai R-Square $\left(\mathrm{R}^{2}\right)$ sebesar $0.022999(0.05 \%)$ menjelaskan bahwa kemampuan variasi nilai panel menjelaskan variasi profitabilitas hanya $2.29 \%$ sedangkan sisanya $98.71 \%$ dijelaskan oleh variabel lain yang tidak dimasukkan dalam model. Koefisien Jumlah ROE tidak signifikan, karena nilai probability lebih besar dari alpha $(0.9311>0.05)$. sedangkan untuk TA hasil menunjukan tidak signifikan, karena nilai probability lebih besar dari alpha $(0.1886>0.05)$ 
Dependent Variable: ABRESID

\section{Tabel 7 \\ Fixed Effect Model}

Method: Panel Least Squares

Date: 03/04/18 Time:20:57

Sample:20122016

Periods included: 5

Cross-sections included: 16

Total panel (balanced) observations: 80

\begin{tabular}{|c|c|c|c|c|}
\hline Variable & Coefficient & Std. Error & t-Statistic & Prob. \\
\hline $\mathrm{C}$ & 0.526450 & 0.073099 & 7.201835 & 0.0000 \\
\hline ROE & 0.003182 & 0.002928 & 1.086714 & 0.2814 \\
\hline TA & $-2.98 \mathrm{E}-12$ & $7.71 \mathrm{E}-12$ & -0.386125 & 0.7007 \\
\hline \multicolumn{5}{|c|}{ Effects Specification } \\
\hline \multicolumn{5}{|c|}{ Cross-section fixed (dum my variables) } \\
\hline R-squared & 0.757304 & \multicolumn{2}{|c|}{ Mean dependent var } & 0.574085 \\
\hline Adjusted R-squared & 0.690758 & \multicolumn{2}{|c|}{ S.D. dependent var } & 0.361937 \\
\hline S.E. of regression & 0.201271 & \multicolumn{2}{|c|}{ Akaike info criterion } & -0.173219 \\
\hline Sum squared resid & 2.511626 & \multicolumn{2}{|c|}{ Schwarz criterion } & 0.362737 \\
\hline Log likelihood & 24.92877 & \multicolumn{2}{|c|}{ Hannan-Quinn criter. } & 0.041661 \\
\hline F-statistic & 11.38022 & \multirow{2}{*}{\multicolumn{2}{|c|}{ Durbin-Watson stat }} & 1.465358 \\
\hline Prob(F-statistic) & 0.000000 & & & \\
\hline
\end{tabular}

\section{Sumber : EViews}

Model Fixed Effect adalah model dengan intercept berbeda-beda untuk setiap subjek (cross section), tetapi slope setiap sujek tidak berubah seiring waktu. Model ini mengasumsikan bahwa intercept adalah berbeda setiap subjrk lainya digunakan variabel dummy.

Nilai R-Square $\left(\mathrm{R}^{2}\right)$ sebesar $0.757304 \quad(0.05 \%)$ menjelaskan bahwa kemampuan variasi nilai panel menjelaskan variasi profitabilitas hanya $75.73 \%$, sedangkan sisanya $25,27 \%$ dijelaskan oleh variabel lain yang tidak dimasukkan dalam model. Koefisien ROE dan TA sama-sama tidak bersignifikan karena nilai probability lebih besar dari pada alpha $(0,2814$ dan $0,7007>0.05)$. 


\section{Tabel 8 \\ Random Effect Model}

Dependent Variable:ABRESID

Method: Panel EGLS (Cross-section random effects)

Date: 03/04/18 Time:20:58

Sample:2012 2016

Periods included: 5

Cross-sections included: 16

Total panel (balanced) observations: 80

Swamy and Arora estimator of component variances

\begin{tabular}{|c|c|c|c|c|}
\hline Variable & Coefficient & Std. Error & t-Statistic & Prob. \\
\hline $\mathrm{C}$ & 0.538249 & 0.104918 & 5.130182 & 0.0000 \\
\hline ROE & 0.002755 & 0.002807 & 0.981479 & 0.3294 \\
\hline TA & $-3.76 \mathrm{E}-12$ & $5.35 \mathrm{E}-12$ & -0.703009 & 0.4842 \\
\hline \multicolumn{5}{|c|}{ Effects Specification } \\
\hline & & & S.D. & Rho \\
\hline \multirow{3}{*}{$\begin{array}{l}\text { Cross-section random } \\
\text { Idiosyncratic random }\end{array}$} & & & 0.328200 & 0.7267 \\
\hline & & & 0.201271 & 0.2733 \\
\hline & \multicolumn{4}{|c|}{ Weighted Statistics } \\
\hline R-squared & 0.020894 & & 0.151840 \\
\hline Adjusted R-squared & -0.004537 & \multicolumn{2}{|c|}{ S.D. dependent var } & 0.198540 \\
\hline S.E. of regression & 0.198989 & \multicolumn{2}{|c|}{ Sum squared resid } & 3.048953 \\
\hline F-statistic & 0.821600 & \multicolumn{2}{|c|}{ Durbin-Watson stat } & 1.227962 \\
\hline \multirow[t]{2}{*}{ Prob(F-statistic) } & 0.443545 & & & \\
\hline & \multicolumn{3}{|c|}{ Unweighted Statistics } & \\
\hline R-squared & 0.016595 & Mean depeno & t var & 0.574085 \\
\hline Sum squared resid & 10.17712 & Durbin-Watsc & stat & 0.571915 \\
\hline
\end{tabular}

Sumber : EViews

Random Effect disebabkan variasi dalam nilai dan arah hubungan antara subjek diasumsikan random yang dispesifikasikan dalam bentuk residual. Model ini mengistimasikan data panel yang variabel residual diduga memiliki hubungan antar subjek.

Nilai R-Square $\left(\mathrm{R}^{2}\right)$ sebesar $0.020894 \quad(0.05 \%)$ menjelaskan bahwa kemampuan variasi nilai panel menjelaskan variasi profitabilitas hanya $2.09 \%$, sedangkan sisanya $98.01 \%$ dijelaskan oleh variabel lain yang tidak dimasukkan dalam model. Koefisien ROE dan TA sama -sama tidak signifikan karena nilai probability yang lebih besar dari 0,05 yatu $(0,3294$ dan $0,4842>0,05)$.

\section{Uji Kecocokan Model}

\section{Tabel 9}

Uji Chow

\begin{tabular}{llll}
\hline Effects Test & Statistic & d.f. & Prob. \\
\hline Cross-section F & 12.505891 & $(15.62)$ & 0.0000 \\
\hline Cross-section Chi-square & 111.414293 & 15 & 0.0000 \\
\hline Sumber : EViews & & &
\end{tabular}


Uji Chow Test (Uji Chow) yakni pengujian untuk menentukan model Common Effect atau Fixed Effect yang paling tepat digunakan dalam mengestimasi data panel. Berdasarkan data yang telah di uji diperoleh nilai probability Cross-section Chi-square lebih kecil dari pada nilai alpha $(0.0000<$ 0.05), maka Ha di tolak. Dengan demikian model Fixed Effect lebih baik digunakan dari model Common Effect.

Tabel 10

Uji Husman Test

\begin{tabular}{llll}
\hline Test Summary & Chi-Sq. Statistic & Chi-Sq. d.f. & Prob. \\
\hline Cross-section & 0.264011 & 2 & 0.8763
\end{tabular}

random

Sumber: EViews

Uji Husman atau yang sering disebut dengan istilah Husman Test adalah uji yang digunakan untuk menentukan metode yang terbaik antara Fixed Effect ataukah Random Effect. Berdasarkan data yang telah diuji bahwa nilai Probability pada Cross-section Random lebih besar dari pada nilai alpha (0.8763 > 0.05) sehingga H0 ditolak. Jika Husman Test menerima $\mathrm{H} 0$ atau $\mathrm{p}$ value $>0.05$, maka metode yang kita pilih adalah Random Effect.

Dari uji yang telah dilakukan baik Uji Chow maupun Uji Hausman, diperoleh model yang terbaik antara Common Effect Model (COM), Fixed Effect Model (FEM), dan Random Effect Model (REM). Hasil estimasi menjlaskan bahwa masing-masing model memiliki nilai signifikansi yanng berbeda. Dari pemilihan model tersebut model yang terbaik diantara ketiga model tersebut adalah Random Effect

\section{Regresi Data Panel Model Terbaik}

\section{Tabel 11}

Dependent Variable: ABRESID

Tabel Hasil Estimasi Random Effect

Method: Panel EGLS (Cross-section random effects)

Date:03/04/18 Time:20:58

Sample:2012 2016

Periods included: 5

Cross-sections included: 16

Total panel (balanced) observations: 80

Swamy and Arora estimator of component variances

\begin{tabular}{ccccc}
\hline \hline Variable & Coefficient & Std. Error & t-Statistic & Prob. \\
\hline \hline C & 0.538249 & 0.104918 & 5.130182 & 0.0000 \\
ROE & 0.002755 & 0.002807 & 0.981479 & 0.3294 \\
TA & $-3.76 E-12$ & $5.35 E-12$ & -0.703009 & 0.4842 \\
\hline \hline & Effects Specification & \multirow{2}{*}{ S.D. } & Rho \\
\hline \hline Cross-section random & & 0.328200 & 0.7267 \\
Idiosyncratic random & & 0.201271 & 0.2733 \\
\hline \hline & & & 0.151840 \\
\hline \hline
\end{tabular}




\begin{tabular}{llll} 
Adjusted R-squared & -0.004537 & S.D. dependent var & 0.198540 \\
S.E. of regression & 0.198989 & Sum squared resid & 3.048953 \\
F-statistic & 0.821600 & Durbin-Watson stat & 1.227962 \\
Prob(F-statistic) & 0.443545 & & \\
\hline \hline & Unweighted Statistics & \\
\hline \hline R-squared & 0.016595 & Mean dependent var & 0.574085 \\
Sum squared resid & 10.17712 & Durbin-Watson stat & 0.571915 \\
\hline \hline
\end{tabular}

Sumber : EViews

Analisis regresi linear data panel pada penelitian ini menggunkan metode Random Effect. Pemilihan model Random Effect sebagai metode analisi data panel yang paling tepat untuk menguji data panel pada penelitian ini. Dari hasil regresi pada model Random Effect didapatkan bahwa nilai koefisien pada ROE 0,002755 dan -3,76E-12 untuk koefisien TA dengan R-square sebesar 0.020894 (2\%) menjelaskan bahwa ROE dan TA menjelaskan nilai variasi perusahaan sebesar $2 \%$. sedangkan sisanya $98 \%$ dijelaskan oleh variabel lain yang tidak dimasukkan dalam model. Sedangkan ROE sebesar 0.3294 tidak berpengaruh signifikan, karena nilai probabilitas lebih besar dari pada alpha $(0.3294<0.05)$. Sementara itu untuk untuk Jumlah Saham Institusional sebesar 0.4842 tidak signifikan, karena nilai probabilitas lebih besar dari nilai alpha $(0.4842>0.05)$.

\section{Uji Hipotesis Untuk Regresi Data Panel}

Uji t statistik menunjukkan seberapa besar pengaruh suatu variabel indepnden terhadap variabel dependen. Hipotesis yang diuji dalam penelitian ini menyatakan bahwa Kinerja Keungan berpengaruh signifikan terhadap Harga Saham dan Ukuran Perusahaan tidak berpengaruh signifikan terhadap Harga Saham. Kriteria pengujian menggunkan taraf signifikansi sebesar 0.05. Apabila nilai probabilitas $\mathrm{T}$ hitung > Ttabel maka Ho ditolakHa diterima dan apabila nilai signifikan > 5\% (0.05) maka Ho diterima dan Ha ditolak. Pada tabel 4.10 menunjukkan bahwa nilai t-statistik Ttabel $(0.002807<1.98896)$ dan lebih kecil dari alpha $(0.0434<$ 0.05) maka Ha diterima dan Ho ditolak, sehingga Kinerja Keungan (ROE) tidak berpengaruh terhadap Harga Saham. Sedangkan untuk Ukuran Perusahaan tstatistik Ttabel $(0.8374<2.0025)$ dan lebih besar dari alpha $(0.9418>0.05)$ sehingga Ho diterima dan Ha ditolak. Jadi kesimpulannya Ukuran Perusahaan (TA) tidak berpengaruh signifikan terhadap profitabilitas.

\section{Pembahasan}

\section{Pengaruh Kinerja Keungan Menggunakan ROE Tehadapa Harga Saham}

Berdasarkan hasil pengolahan data dengan Eviews 8, menunjukkan bahwa kinerja keungan yang dilihat dengan ROE dengan membandingkan laba bersih dengan modal sendiri memiliki pengaruh positif dan tidak signifikan terhadap nilai perusahaan. Hasil ini dibuktikan dengan koefisien ROE yang bernilai +0.002755 dengan tingkat signifikansi $0.3294>$ alpha $=0.05$.

Hasil penelitian ini menjelaskan bahwa para pemegang saham perlu memperhitungkan besar kecilnya nilai ROE, karena besar kecilnya nilai ROE mempengaruhi perubahan harga saham di pasar modal.Meningkatnya ROE berarti terjadi kenaikan keuntungan bersih yang didapatkan perusahaan, kenaikan laba akan menyebabkan kenaikan harga saham perusahaan. Kenaikan harga saham 
akan menyebabkan permintaan saham tinggi sehingga investor menghargai nilai saham perusahaan dan akibatnya nilai perusahaan akan meningkat. Penelitian ini sejalan Sambora, Handayani, \& Rahayu (2014)yang menyatakan bahwa profitabilitas berpengaruh positif dantidak signifikan terhadap nilai perusahaan.

\section{Pengaruh Ukuran Perusahaan Terhadap Harga Saham Perusahaan}

Berdasarkan hasil pengolahan data dengan Eviews 8, menunjukkan bahwa kinerja keungan yang dilihat dengan TA pengaruh negatif dan tidak signifikan terhadap nilai perusahaan. Hasil ini dibuktikan dengan koefisien TA yang bernilai -3.76E-12 dengan tingkat signifikansi $0.4842>$ alpha 0.05 .

Dapat diartikan dalam penelitian ini ukuran perusahaan sangat mempengaruhi harga saham perusahaan. Apabila ukuran perusahaan besar maka investor akan memilih dan membeli saham pada perusahaan tersebut dan sebalik nya apabila ukuran perusahaan kecil maka investor tidak mau menanam kan modal pada perusahaan dan harga saham pun akan menurun.

\section{SIMPULAN}

Berdasarkan penelitian yang telah dilakukan tentang variabel kinerja keungan ROE ( X1) dan ukuran perusahaan TA (X2) terhadap variabel harga saham (Y) maka dapat disimpulkan bahwa nilai t-statistik lebih kecil dari $\mathrm{T}$ tabel $(0.002807<1.98896)$ dan probability lebih kecil dari alpha $(0.0434<0.05)$ maka Ha diterima dan Ho ditolak, sehingga Kinerja Keungan (ROE) tidak berpengaruh terhadap Harga Saham. Sedangkan untuk Ukuran Perusahaan tstatistik lebih kecil dari Ttabel $(0.8374<2.0025)$ dan probability lebih besar dari alpha $(0.9418>0.05)$ sehingga Ho diterima dan Ha ditolak. Jadi kesimpulannya Ukuran Perusahaan (TA) tidak berpengaruh signifikan terhadap profitabilitas.

\section{UCAPAN TERIMAKASIH}

Selesainya penulisan skripsi ini, penulis mengucapkan terima kasih atas bantuan dan dorongan baik secara moral maupun spritual kepada berbagai pihak yaitu kepada Bapak Febryandhie Ananda, SE.,Msi selaku ketua STIE "KBP”, Ibuk Febsri Susanti, SE., MM. Selaku ketua Program Studi Manajemen, Ibuk Aminar Sutra Dewi, SE., M.si selaku dosen pemimbing dari pembuatan skripsi penulis yang banyak membantu penulis dalam menyusun dan memberikan masukan atas pembuatan skripsi, Ibu Maria Magdalena, S.Pd.,MM selaku penasehat Akademik Program Studi Manajemen.

\section{DAFTAR PUSTAKA}

Afriyeni, A., \& Marlius, D. (2017). Analisis Pengaruh Harga Saham Perdana Terhadap Abnormal Return Yang Diterima Investor Studi Pada Bursa Efek Indonesia. https://doi.org/10.31219/osf.io/8z7hx

Afriyeni, A., \& Marlius, D. (2018). Analisis Pengaruh Informasi Prospektus Perusahaan Terhadap Initial Return Saham Pada Pasar Perdana Di Bursa Efek Indonesia. https://doi.org/10.31219/osf.io/kt6c4 
Afriyeni, A., \& Marlius, D. (2019). Analisis Faktor-Faktor Yang Berpengaruh Terhadap Ketepatan Waktu Penyampaian Laporan Keuangan Pada Perusahaan Yang Listing Di Bursa Efek Indonesia. https://oi.org/10.31219/osf.io/rv4qf

Afriyeni, A., \& Marlius, D. (2019). Analisis Tingkat Pengembalian Dan Risiko Investasi (Studi Pada Industri Manufaktur Yang Terdaftar Di Bursa Efek Indonesia). https://doi.org/10.31219/osf.io/cfb92

Amanah, R., \& Azizah, D. F. (2012). Pengaruh Rasio Likuiditas Dan Rasio Profitabilitasterhadap Harga Saham ( Studi pada Perusahaan Indeks LQ45 Periode 2008-2012 ). Jurnal Administrasi Bisnis, 12(1), 1-10.

Ana, S. R. (2016). Pengaruh Laba Akuntansi Dan Arus Kas Serta Ukuran Perusahaan Terhadap Return Saham (Studi Empiris Pada Perusahaan Perbankan Yang Terdaftar Di BEI TAHUN 2012 - 2014) Noviansyah. JURNAL SPREAD, 6(2), 65-76.

Anindya, W. intan. (2015). Analisis Pengaruh Kinerja Keuangan Terhadap Harga Saham Pada Perusahaan Perkebunan Indonesia Intan WoroAnindya. Jurnal Ilmu Dan Riset Manajemen, 4(1), 1-16.

Arifin, I. Z., \& Marlius, D. (2017). Analisis Kinerja Keuangan PT. Pegadaian Cabang Ulak Karang. https://doi.org/10.31227/osf.io/n2peu

Dewi, Aminar Sutra. (2016). Pengaruh Ratio Camel Terhadap Return Saham Pada Pt Bank Mandiri Tbk. Pekbis Jurnal, 8(2), 120-129.

Fahruri, A. (2017). Pengaruh Corporate Governance, Loan to Deposit Ratio , Non Performing Loan, Inflasi dan Kurs Terhadap Kinerja Keuangan Perusahaan Perbankan yang Terdaftar di Bursa Efek Indonesia pada Tahun 2007-2010, $X V(1), 63-70$.

Hapsari, N. M. \& S. putu. (2013). Analisa rasio keuangan untuk menilai kinerja keuangan perusahaan.

Hutami, R. P. (2012). Pengaruh Dividend Per Share, Return On Equity Dan Net Profit Margin Terhadap Harga Saham Perusahaaan Industri Manufaktur Yang Tercatat Di Bursa Efek Indonesia Periode 2006-2010. Jurnal Nominal, I(1), 104-123.

Mayliza, R. (2019). Pengaruh Good Corporate Governance Dan Leverage Terhadap Kinerja Keuangan Pada Perbankan Yang Terdaftar Di BEI. https://doi.org/10.17605/OSF.IO/M9DT6

Moniaga, F. (2013). Struktur Modal, Profitabilitas Dan Struktur Biaya Terhadap 
Nilai Perusahaan Industri Keramik, Porcelen Dan Kaca Periode 2007 - 2011, 1(4), 433-442.

Muliadi, H., \& Fahmi, I. (2017). Pengaruh Dividen Per Share , Return On Equaty Dan Net Profit Margin Terhadap Harga Saham Perusahaan Manufaktur, 1(2), 84-93.

Nugrahani, A. (2016). Pengaruh Kinerja Keuangan dan Ukuran PERUSAHAAN Terhadap Earning Per Share. Jurnal Ilmu Dan Riset Manajemen, 5(1), 1-19.

Rahmayeli, D. S., \& Marlius, D. (2017). Analisis Kinerja Keuangan Pada PT. Bank Perkreditan Rakyat (BPR) Batang Kapas Pesisir Selatan. https://doi.org/10.31227/osf.io/s z5db

Rani, K. S., Nyoman, N., \& Diantini, A. (2015). Pengaruh Kinerja Keuangan Perusahaan Terhadap Harga Saham Dalam Indeks LQ45 DI BEI. E-Jurnal Manajemen Unud, 4(6), 1526-1542.

Raningsih, N. kadek, \& Dwianan Putra, I. made pande. (2015). Pengaruh RasioRasio Keuangan Dan Ukuran Perusahaan Pada Return Saham. E-Jurnal Akuntansi Univesrsitas Udayan, 13(2), 582-599.

Rinati, I. (2008). Pengaruh Net Profit Margin (Npm), Return On Assets( Roa ) Dan Return On Equity ( Roe ) Terhadap Harga Saham Pada Perusahaan Yang Tercantum Dalam Indeks LQ45. Jurusan Akuntansi, 1-12.

Setiyono, E. (2016). Pengaruh Kinerja Keuangan Dan Ukuran Perusahaan Terhadap Return Saham. Jurnal Ilmu Dan Riset Akuntansi, 5(5), 1-17.

Sitompul, S. S. (2008). Analisis Pengaruh Kinerja Keuangan Dan Ukuran Perusahaan Terhadap Harga Saham Pada Perusahaan Infrastructure, Utilities \& Transportation Yang Terdaftar Di Bursa Efek Indonesia.

Sugiyono. (2015). Statistik Nonparametris untuk penelitian (Bayu Rahma).

Sunardi, H. (2010). Pengaruh Penilaian Kinerja dengan ROI dan EVA terhadap Return Saham pada Perusahaan yang Tergabung dalam Indeks LQ 45 di Bursa Efek Indonesia. Jurnal Akuntansi, 2(1), 70-92. Retrieved from http//google scholar

Suselo, D. (2015). Pengaruh Variabel Fundamentaldan Makro Ekonomi terhadap Harga Saham ( Studi pada Perusahaan yang Masuk dalam Indeks LQ45 ). Jurnal Aplikasi Manajemen, 104(1), 104-116.

Susilowati, E., \& Utiyati, S. (2016). Pengaruh Kinerja Keuangan Terhadap Harga Saham. Jurnal Ilmu Dan Riset Manajemen, 5(2), 1-15. 
Ulfa, M. (2014). Pengaruh kinerja keuangan terhadap harga saham bank umum milik pemerintah di bei. Jurnal Ilmu \& Riset Manajemen, 3(11), 1-18.

Utama, T. A., \& Rohman, A. (2013). Pengaruh Corporate Governance Perception Index , Profitabilitas , Leverage , Dan Ukuran Perusahaan Terhadap Nilai Perusahaan. Journal Of Accounting, 2(2), 1-9.

Wandri, A., \& Dewi, A. S. (2019). Pengaruh Leverage, Pertumbuhan Penjualan Dan Ukuran Perusahaan Terhadap Profitabilitas Perusahaan (Studi pada Perusahaan Plastik dan Kemasan yang Terdaftar pada Bursa Efek Indonesia pada Tahun 2012-2016). https $/ /$ doi.org/10.31219/osf.io/9mbhk

Winarno, W. W. (2015). Analisis Ekonometrika dan statistik dengan Eviews (4th ed.). Yogyakarta.

Yahdi, R., \& Dewi, A. S. (2019). Pengaruh Struktur Modal, Ukuran Perusahaan, Dan Profitabilitas Terhadap Nilai Perusahaan Otomotif Yang Terdaftar Di BEI Periode 2012-2016. https://doi.org/10.31219/osf.io/m7xcp

Ysu, Y. (2015). Pengertian Ukuran Perusahaan. Retrieved from http $/ /$ pustakateori.blogspot.co.id/2015/08/pengertian-ukuran-

perusahaan.html 